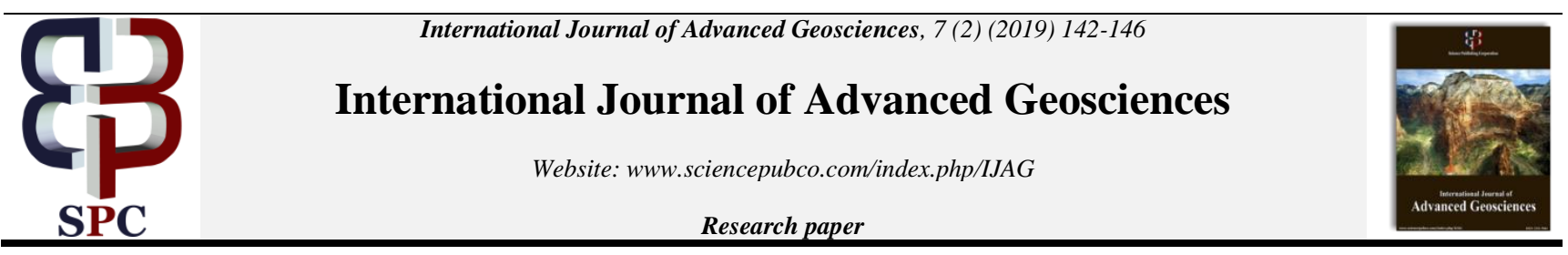

\title{
Shale volume and porosity delineation of coast swamp depobelt in Niger delta region, Nigeria, using well log
}

\author{
Ubong E. Essien * \\ Department of Science Technology, Akwa Ibom State Polytechnic, Ikot Osurua, Akwa Ibom State, Nigeria \\ *Corresponding author E-mail: ubefman@gmail.com
}

\begin{abstract}
Well log data from two wells were evaluated for shale volume, total and effective porosity. Well log data were obtained from gamma ray, neutron-density $\log$, resistivity, sonic and caliper log respectively. This study aimed at evaluating the effect of shale volume, total and effective porosity form two well log data. The results of the analysis depict the presence of sand, sand-shale and shale formations. Hydrocarbon accumulation were found to be high in sand, fair in sand-shale and low in shale, since existence of shale reduces total and effective porosity and water saturation of the reservoir. The thickness of the reservoir ranged from $66-248.5 \mathrm{ft}$. The average values of volume of shale, total and effective porosity values ranged from $0.004-0.299 \mathrm{dec}, 0.178-0.207 \mathrm{dec}$ and $0.154-0.194 \mathrm{dec}$. Similarly, the water saturation and permeability ranged from $0.277-0.447 \mathrm{dec}$ and $36.637-7808.519 \mathrm{md}$ respectively. These values of total and effective porosity are high in sand, fair in sand-shale and low in shale formations. The results for this study demonstrate: accuracy, applicability of these approaches and enhance the proper evaluation of petrophysical parameters from well log data.
\end{abstract}

Keywords: Shale Volume; Effective Porosity; Petrophysical Parameter; Total Porosity; Saturation Exponent.

\section{Introduction}

Shale and porosity are considered the most effective parameters in reservoir characterization (Archie, 1950). Shales are soft finely stratified sedimentary rocks that are formed from consolidated mud or clay and tiny fragments of other minerals such as quartz and calcite. It is more radioactive than sand or carbonate. Shale formation reduces water saturation and other petro physics parameter. However, existence of shale causes an uncertainty which influences the formation evaluation and production. The presence of shale in porous formations present problem from the interpretation of wire line logs, this problem affects the interpretation of resistivity data and the porosity logs (Okwoli et al., 2015). Even small amounts of shale can have a large effect, which is important because most reservoir sands contain some degree of shaliness. Shale material can be distributed in the formation as: dispersed, structural and laminar. Laminated are tiny layers of clay fragments with sand formations, Structural are clayey fragments that form sedimentary rock structures. Disperse are clay particles formed between the open fragments of the clastic matrix. Porosity is a void space inside the rock which store and transmit fluids such as oil, gas and water. Porosity is classified as total porosity and effective porosity. Effective porosity is the vast spaces of porous material that can transmit fluid. Total porosity is the percentage volume occupied by the pore space. Three lithostratigraphic units are identified in the study area: Benin, Agbada and Akata formations (Hosper, 1965, Chopra S and Mechelena, 2011). Akata formation (Eocene to Recent) formed at the base of the delta of marine origin composed of thick shale, turbibite sand, clay and slit. Agbada formation (lower/middle Miocene to Pliocene) consists of shale and sandstone beds of equal proportions which is the major petroleum bearing unit. Benin formation (Miocene to recent) consists of predominantly coastal plain sandstones with local interbred of shale (Weber and Daukorous, 1985). Petroleum in the Niger Delta are trap from sandstones and unconsolidated sand within the Agbada formation in which the main petrophysical properties are porosity, permeability and shale volume that determines the storage and fluid flow capacity for hydrocarbon (Welex, 1978: Whiteman, 1982). This approach identified between porosity and other reservoir properties lead to the evaluation of effective porosity from the total porosity and shale volume. This paper aimed at evaluating the shale volume and effective porosity from wire line logs using Larionov and Archie Equations which saved as accurate method in evaluation of reservoir parameters.

\section{Location and geology of the study area}

The Niger Delta region of Nigeria is a sedimentary basin underlain by, from bottom to top, Akata, Agbada and Benin formations. The Niger Delta comprises of the weathered top soil and unconsolidated coastal plain sands of the Benin formation. The Niger Delta is situated in the Gulf of Guinea which extends to south- south region of Nigeria as shown in Fig. 1 (klett TR et al., 1997, Ameloko, AA and Oweseni, 2015). From Eocene to present, formed depobelts of delta which is the largest regressive deltas in the world with a total of $300,000 \mathrm{~km}^{2}$ and sediments volume/thickness of $500,00 \mathrm{~km}^{3}$ and $10 \mathrm{~km}$ respectively (Kulkie, 1995; Kaplan AL et al., 1994). The Niger Delta is found in the tropical rainforest which is classified into four zones: coastal inland zone, freshwater zone, lowland rainforest zone and mangrove swamp zone (FME et al., 2006; ANEEJ, 2004). The Niger Delta region comprises of eight states, namely: Abia, Akwa 
Ibom, Bayelsa, Cross River, Edo, Ondo, Imo and Rivers, in which one petroleum system has been identified called tertiary Niger Delta. The tertiary Niger Delta is divided into three formations, namely: Benin, Agbada and Akata formations (Hosper, 1965). Akata formation (Eocene to Recent) formed at the base of the delta of marine origin composed of thick shale, turbibite sand, clay and slit of $7000 \mathrm{~m}$ thickness (Stacher,1995). Agbada formation (lower/middle Miocene to Pliocene) consists of shale and sandstone beds of equal proportions which is the major petroleum bearing unit (Okwueze, 2010). Also, comprises of dominantly quartz and polash feldspar with subordinate amounts of plagiodase, kaolinite and ellite with over $3700 \mathrm{~m}$ thickness that represents the actual deltaic portion (Evamy BD et al., 1978). Benin formation (Miocene to recent) consists of predominantly coastal plain sandstones with local interbred of shale of over $2000 \mathrm{~m}$ thickness (Avbovbo, 1978). Geologically, two provinces have been identified in Niger Delta: Onshore and Offshore. The onshore portion is situated in the southern Nigeria and southwestern Cameroon; it is bounded in the north by Benin flanks, east to north by hinge line and south to west by basement Massif which is identified by outcrops of the cretaceous on the Abakaliki High in east and Calabar flank in the south which is bordered by hinge line of adjacent Precambrian (Nyantakyi EK et al., 2013). Offshore boundary of the province is defined by the Cameroon volcanic line of the eastern boundary and west of the Dohomey basin.

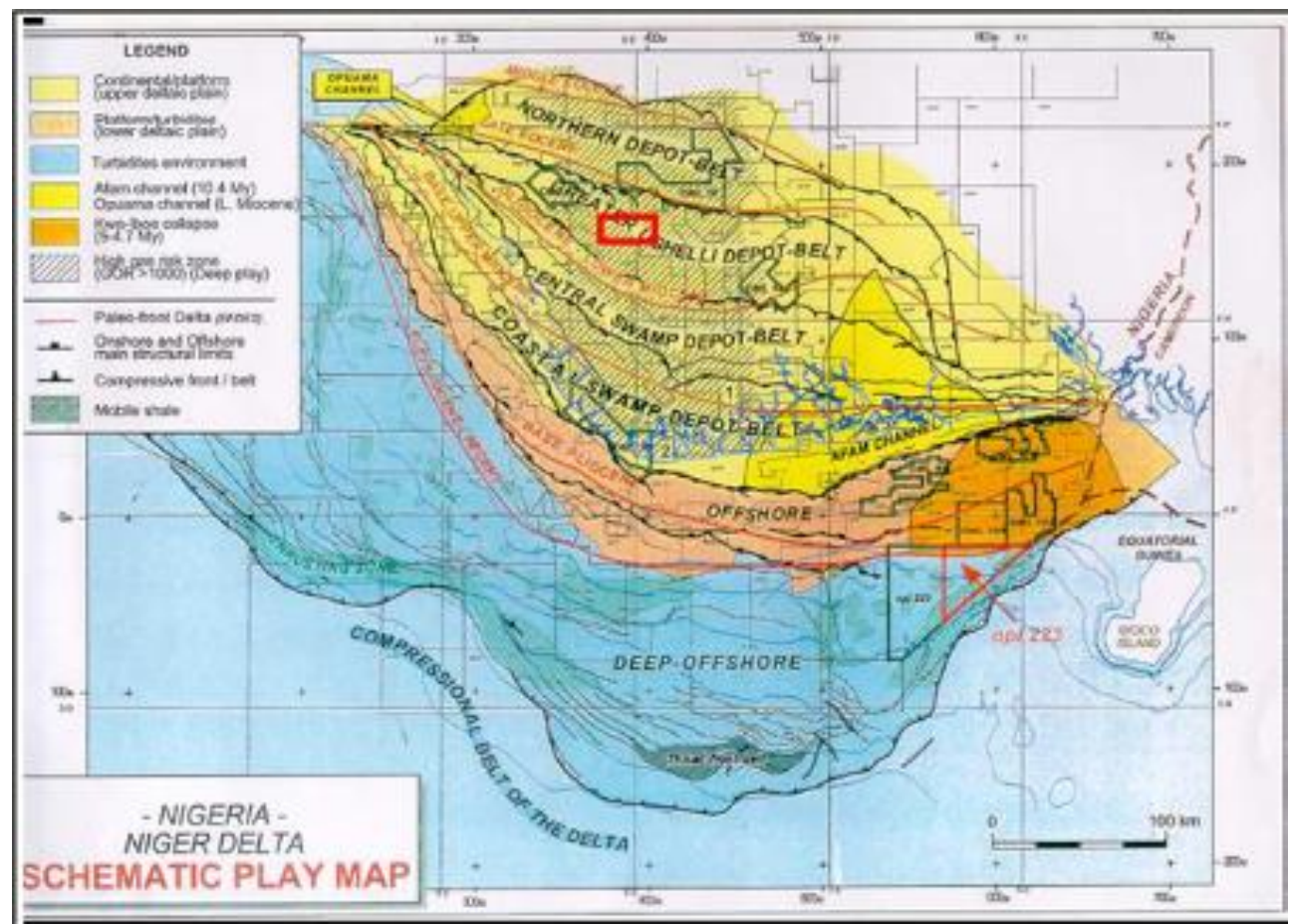

Fig. 1: Map of Nigeria Showing the Study Area.

\section{Methodology}

A total of two well log suite comprising of Caliper, Sonic, Neutron, Gamma Ray, Density logs were analyzed for the evaluation of shale volume and effective porosity of the identified oil and gas reservoirs. The well logs interpretation identify reservoir and provides the output of $\log$ analysis of the reservoir parameters (Asquith G and Gibson, 1982). Fundamentally, high porosity formation reading indicates high value of shale, low sand deposition and low hydrocarbon formation while low porosity formation reading indicates low values of shale, high sand deposition and high hydrocarbon (Chapman, 1983, Eghai JC and Aigbogun, 2012). The first stage in well log analysis is the lithology interpretation which is vital in reservoir characterization. On the other hand, if the lithology interpretation is incorrect, other parameters like shale volume, porosity and effective porosity will be wrong.

Shale volume $\left(V_{\text {sh }}\right)$

Shale volume interpretation is the second stage in well logs analysis by using gamma ray log. The calculation of shale volume is useful in the determination of the water and hydrocarbon saturations, if the reservoir has high shale formation, that reservoir are highly porous with high clayey deposition and water saturation. This is because shale has a high porous ability to retain water. Also, low shale reservoir has high accumulation of hydrocarbon because formation with low shale volume has high permeability and vice versa. It is expressed as shown in Eqs. 1 to 3.

Volume of Shale

In 1969, Larionov proposed two formulas to calculate the shale volume which includes:

Tertiary rocks:

$V_{S h}=0.083\left(2^{3.7 l_{C R}}-1\right)$

Older rocks:

$V_{s h}=0.33\left(2^{2 l_{C R}}-1\right)$

$\mathrm{I}_{G R}=\frac{G R_{\text {Log }}-G R_{\text {Min }}}{G R_{\text {Max }}-G R_{\text {Min }}}$ 
Where $\mathrm{I}_{\mathrm{GR}}$ is the index gamma ray, Vsh is the volume of shale, GRlog is the gamma ray reading, GRmax is the gamma ray maximum reading and GRmin is the gamma ray minimum reading.

Porosity

Porosity calculation is the third stage in well log analysis. Porosity depends on the lithology interpretation. However, if the lithology interpretation is correct, porosity interpretation will be correct. It could be calculated using density log, sonic log, neutron log, or combination between neutron-density logs. Below shows the calculation of porosity using Archie's equation as expressed in Eqs. 4 to 7.

Archie's Equation $\Phi=\frac{\text { Sonic } \log v a l u e-55.5}{189-55.5}$

Where $55.5=\Delta \mathrm{t}_{\mathrm{ma}}$ is the sandstone constant sonic log value, $189=\Delta \mathrm{t}_{\text {fluid }}$ is the fluid constant sonic log value.

$$
\Phi^{m}=\frac{a}{F}
$$

Where $\mathrm{a}$ is tortuosity sand factor ' $\mathrm{a}$ ' $=1, \mathrm{~m}$ is the compaction sand exponent factor ' $\mathrm{m}$ ' $=2$

$$
\Phi=\frac{\rho_{\text {ma }} \rho_{b}}{\rho_{\text {ma }} \rho_{f}}
$$

Where $\rho_{\text {ma }}$ is the matric density, $\rho_{b}$ is the bulk density and $\rho_{f}$ is the fluid density

$$
\Phi^{m}=\frac{R_{w}}{S_{w}^{n} R_{t}}
$$

Where $S_{w}^{n}$ water saturation, $\mathrm{n}$ is the saturation exponent, $R_{t}$ true formation resistivity and $R_{w}$ is formation water resistivity

Effective Porosity

Effective porosity is the differences between the total porosity and the product of the volume of shale with shale porosity fractions. In a formation that is highly sandy with zero shale deposition, the effective porosity is equal to total porosity. That is, volume of the shale is equal to zero. However; effective porosity formation illustrates a pore space that contains high hydrocarbon and low clayey deposition. The effective and total porosities relationship can be expressed as shown in shale sand reservoir, Archie Eqns. 7 to 10.

Archie's Equation

Shale sand reservoir

$$
\Phi_{\varepsilon}=\Phi_{t}-V_{s h} \times \Phi_{s h}
$$

$\Phi_{t}=$ fraction of total porosity; $\Phi_{e}=$ fraction of effective porosity; $\mathrm{V}_{\mathrm{sh}}=$ fraction of volume of shale and $\Phi_{s h}=$ fraction of shale porosi-

ty. However, shale porosity can also be determined by substituting shale porosity $\Phi_{s h}$ with total porosity $\Phi_{t}$ to get Eq. 8 .

Shale reservoir

$$
\Phi_{\varepsilon}=\Phi_{t}-V_{s h} \times \Phi_{t}
$$

Shale-bound water

$$
\Phi_{\varepsilon}=\Phi_{t}-V_{c b w}
$$

$\mathrm{V}_{\mathrm{cbw}}=$ fraction of volume of clay or shale-bound water. The volume of the clay bound water replaced the shale volume and its porosity. This can be obtained using elemental capture spectroscopy (ECS).

\section{Results and discussion}

Well log data from two wells was used for this study. Shale volume, total and effective porosity were calculated along with other parameters and three formation zones were identified in the reservoirs. The important parameters of larionov equation for shale volume calculation is the gamma ray index from gamma ray log, in Archie equation are: 'm' compaction factor, ' $n$ ' saturation exponent and 'a' tortuosity factor. For water saturation and resistivity, the compaction factor and saturation exponent is equal to 2 and tortuosity factor is equal 1 due to its variation in different formation. Tables 1 to 2 and Figs. 2 to 3 show the analysis of shale volume, porosity and other reservoir properties in well 1 and 2 . In each of the wells, three reservoirs where identified.

In well 1 , mean value of the shale volume for the reservoirs is between $0.197-0.299 \mathrm{dec}$, mean effective porosity for the reservoirs is between $0.164-0.194 \mathrm{dec}$, mean total porosity for the reservoirs is between $0.182-0.207 \mathrm{dec}$ permeability for the reservoirs is between $3559.977-7808.519 \mathrm{md}$, water saturation for the reservoirs is between $0.277-0.328 \mathrm{dec}$ respectively. This reservoir indicates a fair hydrocarbon accumulation with reservoir one and two identified as an Oil reservoir while reservoir three is a Gas reservoir. 
Table 1: Reservoir Parameters of Well 1

\begin{tabular}{|c|c|c|c|c|c|c|c|c|c|c|}
\hline \multicolumn{2}{|l|}{ Reservoir } & \multicolumn{3}{|c|}{$\begin{array}{l}\text { Top: } 10470 \mathrm{ft}, \text { Bottom: } 10718 \mathrm{ft} \text {, Net: } \\
248.5 \mathrm{ft}\end{array}$} & \multicolumn{3}{|c|}{$\begin{array}{l}\text { Top: } 10905.5 \mathrm{ft}, \text { Bottom: } 11069 \mathrm{ft} \text {, Net: } \\
164 \mathrm{ft}\end{array}$} & \multicolumn{3}{|c|}{$\begin{array}{l}\text { Top: } 11178 \mathrm{ft}, \text { Bottom: } 11287 \mathrm{ft} \text {, Net: } \\
109.5 \mathrm{ft}\end{array}$} \\
\hline Curve & Units & Min & Max & Mean & Min & Max & Mean & Min & Max & Mean \\
\hline Caliper & in & 7.034 & 8.573 & 7.525 & 7.313 & 10.495 & 8.48 & 8.022 & 10.86 & 8.704 \\
\hline Density & $\begin{array}{l}\mathrm{g} / \mathrm{cm} \\
3\end{array}$ & 2.109 & 2.341 & 2.132 & 2.109 & 2.522 & 2.196 & 2.109 & 2.348 & 2.172 \\
\hline Gamma & gAPI & 7.194 & 91.553 & 36.653 & 6.69 & 111.773 & 52.344 & 16.518 & 92.498 & 51.068 \\
\hline $\begin{array}{l}\text { Permeabil- } \\
\text { ity }\end{array}$ & $\mathrm{md}$ & 7.488 & 45851.36 & 3559.977 & 0.067 & 19410.08 & 3693.415 & 7.037 & 30163.64 & 7808.519 \\
\hline PHIE & Dec & 0.105 & 0.208 & 0.194 & 0.029 & 0.202 & 0.164 & 0.097 & 0.198 & 0.17 \\
\hline PHIT & Dec & 0.141 & 0.219 & 0.207 & 0.073 & 0.212 & 0.182 & 0.132 & 0.208 & 0.188 \\
\hline Resistivity & $\begin{array}{l}\text { ohm } \\
\text { m }\end{array}$ & 3.457 & 870.131 & 63.923 & 3.991 & 320.137 & 63.065 & 3.766 & 438.999 & 125.296 \\
\hline Sonic & $\mathrm{us} / \mathrm{ft}$ & 72.806 & 112.111 & 91.482 & 78.436 & 102.843 & 90.482 & 80.951 & 101.842 & 92.106 \\
\hline SW & Dec & 0.035 & 0.854 & 0.328 & 0.055 & 1 & 0.358 & 0.046 & 0.863 & 0.277 \\
\hline Vsh & Dec & 0.004 & 0.555 & 0.197 & 0.001 & 0.687 & 0.299 & 0.065 & 0.561 & 0.291 \\
\hline
\end{tabular}

Nomenclature BVW = Bulk volume of water, PHIE $=$ Effective Porosity, $\mathrm{PHIT}=$ Total Porosity, $\mathrm{SW}=$ Water saturation, $\mathrm{V}_{\text {sh }}=\mathrm{Volume}$ of shale

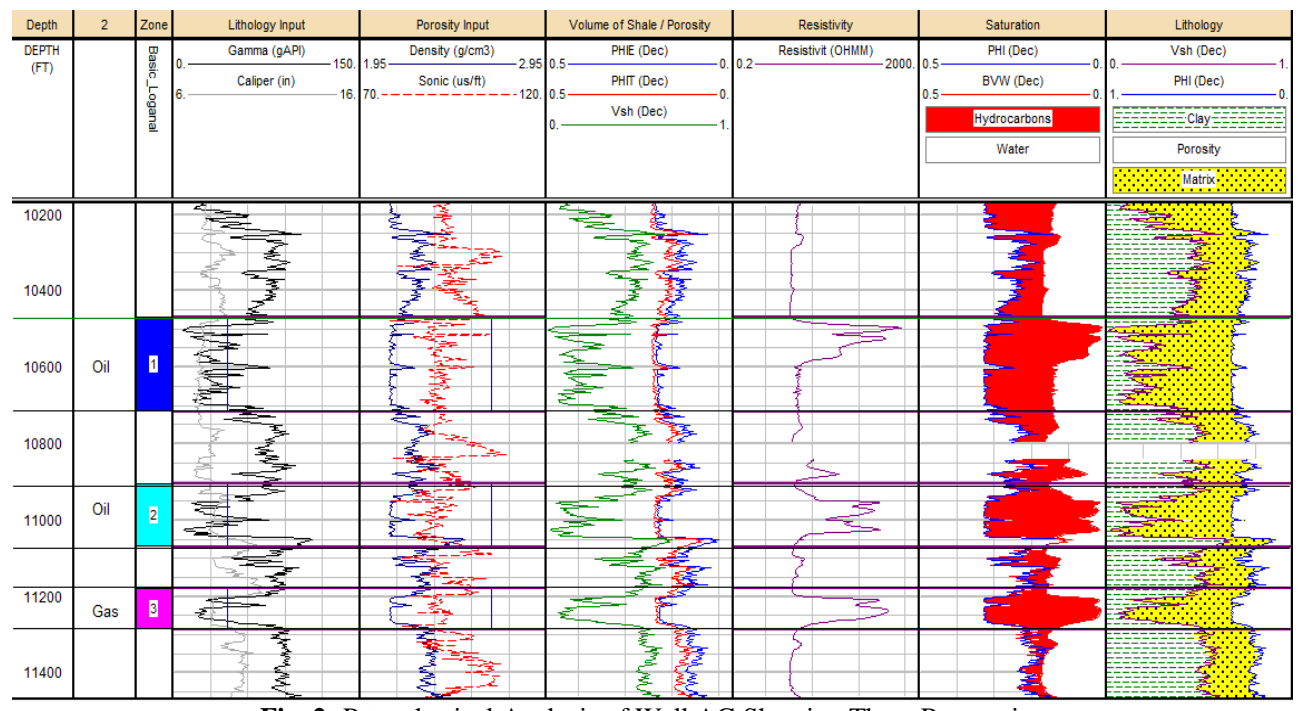

Fig. 2: Petrophysical Analysis of Well AG Showing Three Reservoirs.

In well 2 , mean value of the shale volume for the reservoirs is between $0.004-0.031 \mathrm{dec}$, mean effective porosity for the reservoirs is between $0.154-0.163 \mathrm{dec}$, mean total porosity for the reservoirs is between $0.178-0.190 \mathrm{dec}$ permeability for the reservoirs is between $39.775-50.147 \mathrm{md}$, water saturation for the reservoirs is between $0.434-0.447 \mathrm{dec}$ respectively. This reservoir indicates a fair hydrocarbon accumulation with reservoir one and three identified as an Oil reservoir while reservoir two is a Gas reservoir.

Based on the analysis, high hydrocarbon accumulation is attributed to sand zone with a corresponding high effective porosity and low shale volume, fair hydrocarbon zone is attributed to sand-shale zone while low hydrocarbon accumulation is attributed to shale zone with low effective porosity and high shale volume values. The low values of the effective porosity depict grain size effect within the reservoir sand. Subsequently, the reservoir indicates less accumulation of hydrocarbon from shale formation, high hydrocarbon accumulation from sand and fair hydrocarbon accumulation in sand- shale formation which decrease with increasing depth.

Table 2: Reservoir Parameters of Well 2

\begin{tabular}{|c|c|c|c|c|c|c|c|c|c|c|}
\hline \multicolumn{2}{|l|}{ Reservoir } & \multicolumn{3}{|c|}{$\begin{array}{l}\text { Top: } 10026.5 \mathrm{ft} \text {, Bottom: } 10092 \mathrm{ft}, \text { Net: } \\
66 \mathrm{ft}\end{array}$} & \multicolumn{3}{|c|}{$\begin{array}{l}\text { Top: } 10211.5 \mathrm{ft}, \text { Bottom: } 10368 \mathrm{ft} \text {, Net: } \\
157 \mathrm{ft}\end{array}$} & \multicolumn{3}{|c|}{$\begin{array}{l}\text { Top: } 10635 \mathrm{ft}, \text { Bottom: } 10770 \mathrm{ft}, \mathrm{Net}: \\
135.5 \mathrm{ft}\end{array}$} \\
\hline Curve & Units & Min & Max & Mean & Min & $\operatorname{Max}$ & Mean & Min & Max & Mean \\
\hline Caliper & in & 12.091 & 12.514 & 12.174 & 12.19 & 12.453 & 12.247 & 11.919 & 12.63 & 12.063 \\
\hline Density & $\begin{array}{l}\mathrm{g} / \mathrm{cm} \\
3\end{array}$ & 2.14 & 2.454 & 2.258 & 2.161 & 2.534 & 2.235 & 2.171 & 2.516 & 2.264 \\
\hline Gamma & gAPI & 31.758 & 92.922 & 43.602 & 27.417 & 109.045 & 50.801 & 27.675 & 102.621 & 47.412 \\
\hline $\begin{array}{l}\text { Permeabil- } \\
\text { ity }\end{array}$ & $\mathrm{md}$ & 0.655 & 150.423 & 39.755 & 0.042 & 109.507 & 50.147 & 0.08 & 106.147 & 36.637 \\
\hline PHIE & Dec & 0.093 & 0.206 & 0.161 & 0.053 & 0.199 & 0.163 & 0.064 & 0.191 & 0.154 \\
\hline PHIT & Dec & 0.123 & 0.228 & 0.184 & 0.11 & 0.216 & 0.19 & 0.114 & 0.207 & 0.178 \\
\hline Resistivity & $\begin{array}{l}\mathrm{ohm} \\
\mathrm{m}\end{array}$ & 2.294 & 6.019 & 3.401 & 1.947 & 4.907 & 3.031 & 2.368 & 5.645 & 3.338 \\
\hline Sonic & $\mathrm{us} / \mathrm{ft}$ & 82.4 & 104.75 & 87.253 & 74.863 & 95.063 & 86.852 & 69.275 & 91.75 & 85.859 \\
\hline SW & Dec & 0.343 & 0.643 & 0.436 & 0.346 & 0.924 & 0.434 & 0.332 & 0.836 & 0.447 \\
\hline Vsh & Dec & 0 & 0.3 & 0.004 & 0 & 0.521 & 0.031 & 0 & 0.433 & 0.017 \\
\hline
\end{tabular}




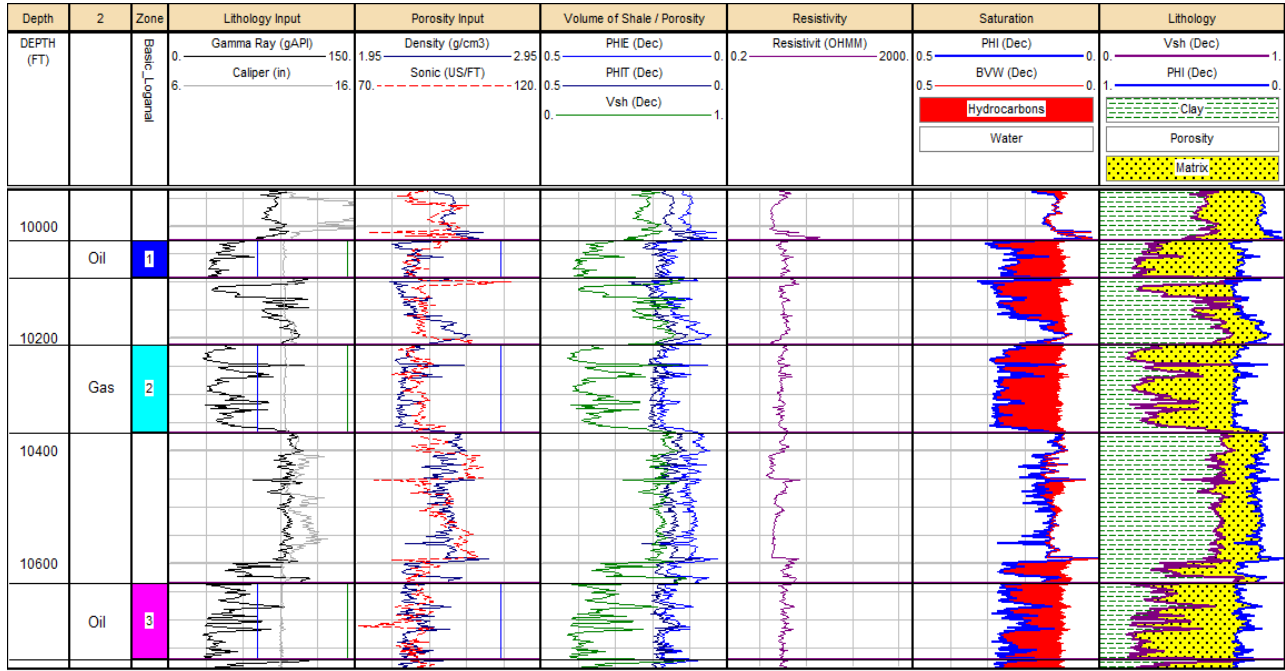

Fig. 3: Petrophysical Analysis of Well AG Showing Three Reservoirs.

\section{Conclusion}

The present work evaluates shale volume and effective porosity from two wells data using Larionov and Archie equations. The result from well log depicts three reservoirs. The thickness of the reservoir ranged from $109.5-248.5 \mathrm{ft}$ and $66-135.5 \mathrm{ft}$ for well 1 and 2 respectively. Shale volumes, effect and total porosity are respectively. The permeability values in well $1(36.637-50.147 \mathrm{md})$ corresponds to low values of volume of shale $(0.004-0.017)$. However, the existence of shale in a formation reduces effective porosity and water saturation which causes an uncertainty and influences the oil and gas formation evaluation and production

\section{References}

[1] Ameloko, A.A. and Owoseni, A.M. (2015). Hydrocarbon Reservoir Evaluation of X-Field, Niger Delta using Seismic and Petrophysical Data. International Journal of Innovation and Scientific Research, 15(1): 193-201.

[2] Aneej (2004). Oil of Poverty in the Niger Delta. A publication of the African Network for Environment and Economic Justice, 4(2): 53-59.

[3] Archie,G.E.(1952). Classification of Carbonate Reservoir Rocks and Petrophysical consideration. American Association of Petroleum Geologist, Bulletin, 4(2):10-18.

[4] Asquith, G and Gibson. (1982). Basic Well Log Analysis for Geologists. American Association of Petroleum Geologist. Methods for Exploration Series, 2(3), 12-18.

[5] Avbovbo, A. A. (1978). Tertiary Lithostratigraphy of Niger Delta: American Association of Petroluem Geologists Bulletin, 62: 295-300. https://doi.org/10.1306/C1EA482E-16C9-11D7-8645000102C1865D.

[6] Chapman, R.E. (1983): The logging of Boreholes. Petroleum Geology, Concise Study, Elsevier, Ameterdium 107-157. https://doi.org/10.1016/S0376-7361(08)70090-6.

[7] Chopra, S and Mechelena, R. J. (2011) Introduction to this Special Section: Reservoir Characterisation: The Leading Edge 30 No.1,35. https://doi.org/10.1190/1.3535430.

[8] Egbai, J.C and Aigbogun, C.O. (2012). Seismic Refraction Profiling and Vertical Electrical Sounding for Ground Water Study in Obiaruku, Delta State, Nigeria. IJRAS, 10(2): 12-17

[9] Evamy, B.D, Harembource .J. and Kamerly, P. (1978). Hydrocarbon Habit of Tertiary Niger Delta. American Association of Petroleum Geologist. Bulletin, 6(2): 1-29.

[10] FME: Federal Ministry of Environment (2006). Niger Delta Natural Resourses Damage Assessment and Restoration Project, Phase 1 Scoping Report (Abuja: Federal Ministry of Environment, 2006), 5(2): 10-15.

[11] Hopers, J. (1965). Gravity Field and the Structure of the Niger Delta Nigeria. Geologist Society of American Bulletin, 7(6): 407-422. https://doi.org/10.1130/0016-7606(1965)76[407:GFASOT]2.0.CO;2.

[12] Kaplan,A ., Lusser, C.U. \& Norton, I.O.(1994). Tectonic Map of the World, Panel 10: Tulsa, American Association of Petroleum Geologists, Scale1: $10,000,000$

[13] Klett, T. R., Ahlbrandt, T. S., Schmoker, J. W. \& Dolton, J. L. (1997). Ranking of the World's Oil and Gas Provinces by known Petroluem Volumes: United State. Geological Survey Open File Report.97-463. https://doi.org/10.3133/ofr97463.

[14] Nyantakyi, E. K., Wangshui, H. U., Korkole, J. K., Qin, G. and Han, M. C., (2013). Structural and Strategic Mapping of Delta Field, Agbada Formation, Offshore Niger Delta, Nigeria. American Journal of Engineering Research (AJER) 11/2013, 2(11): 204-215.

[15] Okwoli, E., Obiora, D.N, Adewoye, O., Chukudebelu, Ezema, P.O. (2015). Reservoir Characterization and Volumetric Analysis of Lona Field Niger, Delta using 3D Seismic and Well Log Data. Petroleum and Coal, 57(2): 108-119.

[16] Okwueze, E. E., (2010) Geophysics in the Service of Mankind: 47 th Inaugural Lecture University of Calabar. P.7.

[17] Kulkie,H. (1995). Nigeria, In Kulke, H., (Ed)., Regional Petroluem Geology of the World.Part 11: Africa, America, Australia and Antarctica: Berlin: Gebruder Borntraeger, 143-172.

[18] Stacher,P. (1995). Present Understanding of the Niger Delta Hydrocarbon Habitat, In Oti, M.N., \& Postma, G., (Ed)., Geology of Deltas. Roterdam: A. A. Balkema, 257-267.

[19] Weber, K.J and Daukoru, E.M. (1985). Petroleum Geology of the Niger Delta (9 $9^{\text {th }}$ World) Petroleum Congress Proceeding: Tokyo, Japan, 6(2): 209-221.

[20] Welex, (1978). An Introduction to Well Log Analysis: Houston, Texas, 46.

[21] Whiteman, I.K. (1982): Fundamental of Reservoir Engineering, $4^{\text {th }}$ ed. Norman, University of Oklahoma.426. 